\title{
Pengaruh model problem based learning terhadap kemampuan berpikir kritis pada kompetensi atmosfer siswa kelas X MIA SMAN 3 Batu
}

\author{
Tria Arta Violina, Budi Handoyo*, Djoko Soelistijo \\ Universitas Negeri Malang, Jl. Semarang No. 5 Malang, Jawa Timur, Indonesia \\ *Penulis korespondensi, Surel: budi.handoyo.fis@um.ac.id
}

Paper received: 01-04-2021; revised: 15-04-2021; accepted: 30-04-2021

\begin{abstract}
Abstrak
Penelitian ini bertujuan untuk mengetahui pengaruh model Problem Based Learning terhadap kemampuan berpikir kritis pada kompetensi atmosfer siswa kelas X MIA SMAN 3 Batu. Penelitian ini dilakukan dengan menggunakan rancangan penelitian eksperimen semu dengan menggunakan Nonequivalent Group Design. Subjek penelitian ini yaitu siswa kelas X MIA 1 sebagai kelas kontrol dan siswa kelas X MIA 2 sebagai kelas eksperimen. Instrumen yang digunakan dalam penelitian berupa tes esai yang terdiri dari 5 butir soal. Analisis data dilakukan dengan menggunakan software SPSS 16.0 for windows. Pengujian hipotesis dilakukan dengan analisis uji-t. Hasil perhitungan hipotesis menunjukkan nilai signifikansi 0,000 kurang dari 0,05.
\end{abstract}

Kata kunci: model problem based learning; kemampuan berpikir kritis

\section{Pendahuluan}

Berpikir merupakan suatu kegiatan yang selalu dilakukan oleh manusia. Berpikir merupakan kata yang berasal dari kata dasar pikir. Kata pikir memiliki pengertian ikatan, akal budi, angan-angan (Kamus Besar Bahasa Indonesia, 2010). Berpikir memiliki pengertian sebagai kegiatan berpikir dan menggunakan akal. Berpikir dalam kajian psikologis secara tegas menelaah proses dan pemeliharaan untuk suatu aktivitas yang berisi mengenai bagaimana yang dihubungkan dalam gagasan-gagasan yang diarahkan untuk beberapa tujuan yang diharapkan (Kuswana, 2011).

Kemampuan berpikir kritis merupakan suatu kemampuan yang dimiliki individu untuk melihat dan memecahkan masalah yang ditandai dengan sifat-sifat dan bakat kritis yaitu mempunyai rasa ingin tahu yang tinggi imajinatif dan selalu tertantang oleh kemajemukan, berani mengambil resiko, dan mempunyai sifat yang tak kalah adalah selalu menghargai hakhak orang lain, arahan bahkan bimbingan orang lain. Pada zaman modern ini kemampuan berpikir kritis sangatlah diperlukan agar kedepannya siswa dapat memiliki kualitas sumber daya manusia yang baik dan dapat bersaing.

Indikator kemampuan berpikir kritis yang digunakan dalam penelitian ini adalah sebagai berikut: (1) memberi penjelasan awal, (2) membangun keterampilan dasar, (3) membuat kesimpulan, (4) memberikan penjelasan lanjut, dan (5) mengatur strategi dan taktik. Apabila seorang siswa telah mampu melampaui indikator-indikator tersebut, maka dapat disimpulkan bahwa siswa tersebut memiliki kemampuan berpikir kritis yang tinggi.

Guna meningkatkan kemampuan berpikir kritis siswa, maka terdapat beberapa model pembelajaran yang disarankan, yaitu model pembelajaran yang tidak menggunakan metode ceramah dan menghafal. Kecenderungan model yang digunakan memiliki penekanan pada 
pembelajaran yang berbasis aktivitas, menginspirasi, dan berprakarsa bagi siswa. Model pembelajaran yang dimaksudkan seperti model pembelajaran Discovery Learning, Project Based Learning, dan Problem Based Learning. Discovery learning merupakan model pembelajaran yang berbasis penemuan. Project based learning merupakan model pembelajaran yang berbasis proyek. Problem based learning merupakan model pembelajaran yang berbasis masalah.

Salah satu model pembelajaran yang sesuai untuk diterapkan adalah model pembelajaran berbasis masalah atau biasa disebut dengan Problem Based Learning (PBL). PBL merupakan penggunaan berbagai macam kecerdasan yang diperlukan untuk melakukan konfrontasi terhadap tantangan dunia nyata, kemampuan untuk menghadapi segala sesuatu yang baru dan kompleksitas yang ada (dalam Rusman, 2012). PBL adalah metode pengajaran yang bercirikan adanya permasalahan nyata sebagai konteks untuk para peserta didik belajar berpikir kritis dan keterampilan memecahkan masalah, dan memperoleh pengetahuan (Duch, 1995).

Fokus utama dari PBL adalah mendorong siswa agar dapat memecahkan permasalahan yang diberikan oleh guru dengan kemampuan berpikir tingkat tinggi atau yang biasa disebut dengan Higher Order Thinking Skills (HOTS). Hal ini didasari karena, dengan memberikan berbagai studi kasus atau permasalahan, diharapkan siswa dapat mendapatkan pemahaman yang konstruktif dan bersifat utuh, sehingga seiring berjalannya waktu, materi yang disampaikan dapat tetap tersimpan dengan baik pada ingatan siswa.

Model PBL dapat diaplikasikan dengan baik apabila kegiatan belajar mengajar yang dilakukan telah sesuai dengan sintaks berikut ini: (1) memberi orientasi permasalahan kepada siswa; (2) mengorganisasi siswa untuk belajar; (3) membantu siswa melakukan pemecahan masalah; (4) mengembangkan penyajian hasil; (5) menganalisis dan melakukan evaluasi proses pemecahan masalah.

Materi yang sesuai untuk diaplikasikan dengan menggunakan model PBL salah satunya adalah materi tentang atmosfer. Materi ini dipilih karena dirasa sesuai dengan karakteristik model PBL yang menggunakan masalah sebagai basisnya. Pembahasan mengenai atmosfer memiliki banyak permasalahan ril yang dapat dimanfaatkan oleh siswa untuk membentuk kemampuan berpikir kritisnya. Hal ini dikarenakan masalah mengenai atmosfer kerap kali dijumpai oleh siswa pada kehidupan sehari-hari. Tujuan dari penelitian ini adalah untuk mengetahui pengaruh yang ditimbulkan dari penggunaan model PBL terhadap kemampuan berpikir kritis siswa pada kompetensi atmosfer.

\section{Metode}

Penelitian ini menggunakan rancangan penelitian eksperimen semu (Quasi Experiment). Pada penelitian ini desain yang digunakan yaitu Non-equivalent group design. Subjek dalam penelitian ini adalah siswa kelas X MIA 1 dan kelas X MIA 2. Penelitian dilakukan di SMAN 3 Batu pada tahun pelajaran 2018/2019. Pada penelitian ini pengambilan subjek dilakukan dengan cara acak, dan menghasilkan kelas X MIA 1 sebagai kelas kontrol, sedangkan kelas X MIA 2 sebagai kelas eksperimen.

Kelas X MIA 1 sebagai kelas kontrol akan diajar dengan menggunakan model Cooperative Learning, sedangkan kelas X MIA 2 sebagai kelas eksperimen akan diajar dengan 
menggunakan model PBL. Pemilihan model Cooperative Learning dan model PBL dilakukan agar tidak terjadi ketimpangan antar kelas eksperimen dan kelas kontrol.

Instrumen yang digunakan untuk mengukur variabel terikat kemampuan berpikir kritis dalam penelitian ini yakni berupa soal essay yang berjumlah 5 butir dengan ranah $C 4$ dalam taksonomi Bloom. Sebelum diberikan kepada siswa, soal sebelumnya telah diuji validitas dan reliabilitas, sehingga peneliti dapat memastikan bahwa soal sudah valid dan reliabel. Teknik analisis data dalam penelitian ini menggunakan software SPSS 16.0 for windows.

\section{Hasil dan Pembahasan}

Data hasil dari penelitian ini dapat dilihat pada Tabel 1.

Tabel 1. Distribusi Frekuensi Data Kemampuan Awal Siswa Kelas Eksperimen

\begin{tabular}{lllll}
\hline Klasifikasi & Nilai & Kualifikasi & Frekuensi & Presentase \\
\hline A & $90-100$ & Sangat Tinggi & 0 & $0 \%$ \\
B & $80-89$ & Tinggi & 4 & $13,33 \%$ \\
C & $70-79$ & Sedang & 15 & $50 \%$ \\
D & $60-69$ & Rendah & 7 & $23,34 \%$ \\
E & $0-59$ & Sangat Rendah & 4 & $13,33 \%$ \\
\hline
\end{tabular}

Tabel 1 menjelaskan bahwa separuh (50\%) siswa dapat dikategorikan memiliki kemampuan berpikir kritis sedang, sejumlah $23,34 \%$ siswa termasuk dalam kualifikasi rendah, $13,33 \%$ siswa termasuk dalam kualifikasi tinggi dan sangat rendah, dan terdapat $0 \%$ siswa yang memiliki kemampuan berpikir kritis sangat tinggi.

Tabel 2. Distribusi Kemampuan Akhir Berpikir Kritis Siswa Kelas Eksperimen

\begin{tabular}{lllll}
\hline Klasifikasi & Nilai & Kualifikasi & Frekuensi & Presentase \\
\hline A & $90-100$ & Sangat Tinggi & 11 & $36,67 \%$ \\
B & $80-89$ & Tinggi & 17 & $56,67 \%$ \\
C & $70-79$ & Sedang & 2 & $6,66 \%$ \\
D & $60-69$ & Rendah & 0 & $0 \%$ \\
E & $0-59$ & Sangat Rendah & 0 & $0 \%$ \\
\hline
\end{tabular}

Tabel 2 menjelaskan bahwa 56,67\% siswa memiliki kemampuan berpikir kritis yang tinggi. 36,67\% siswa dikategorikan memiliki kemampuan berpikir kritis sangat tinggi, sejumlah 6,67\% siswa termasuk dalam kualifikasi sedang, dan terdapat $0 \%$ siswa yang memiliki kemampuan berpikir kritis rendah dan sangat rendah.

Tabel 3. Distribusi Frekuensi Data Kemampuan Awal Siswa Kelas Kontrol

\begin{tabular}{lllll}
\hline Klasifikasi & Nilai & Kualifikasi & Frekuensi & Presentase \\
\hline A & $90-100$ & Sangat Tinggi & 0 & $0 \%$ \\
B & $80-89$ & Tinggi & 2 & $6,67 \%$ \\
C & $70-79$ & Sedang & 9 & $30 \%$ \\
D & $60-69$ & Rendah & 14 & $46,66 \%$ \\
E & $0-59$ & Sangat Rendah & 5 & $16,67 \%$ \\
\hline
\end{tabular}


Tabel 3 menunjukkan bahwa mayoritas siswa, yakni sebesar 46,66\% tergolong dalam kualifikasi rendah, sebesar $30 \%$ siswa tergolong dalam kualifikasi sedang, sebesar $16,67 \%$ siswa tergolong dalam kualifikasi sangat rendah, terdapat 6,67\% siswa tergolong dalam kualifikasi tinggi, dan terdapat $0 \%$ siswa yang tergolong dalam kualifikasi sangat tinggi.

Tabel 4. Distribusi Kemampuan Berpikir Kritis Siswa Kelas Kontrol

\begin{tabular}{lllll}
\hline Klasifikasi & Nilai & Kualifikasi & Frekuensi & Presentase \\
\hline A & $90-100$ & Sangat Tinggi & 3 & $10 \%$ \\
B & $80-89$ & Tinggi & 20 & $66,67 \%$ \\
C & $70-79$ & Sedang & 7 & $20,33 \%$ \\
D & $60-69$ & Rendah & 0 & $0 \%$ \\
E & $0-59$ & Sangat Rendah & 0 & $0 \%$ \\
\hline
\end{tabular}

Tabel 4 menunjukkan bahwa mayoritas siswa memiliki kemampuan berpikir kritis yang tinggi, yakni sebesar $66,67 \%$. Terdapat $20,33 \%$ siswa yang termasuk dalam kualifikasi sedang, $10 \%$ siswa yang termasuk dalam kualifikasi sangat tinggi, dan $0 \%$ siswa yang termasuk dalam kualifikasi rendah dan sangat rendah.

Tabel 5 Hasil Perhitungan Uji Hipotesis

\begin{tabular}{llll}
\hline Kelas & $\mathrm{N}$ & Mean & Sig. \\
\hline Eksperimen & 30 & 87.23 & 0.000 \\
Kontrol & 30 & 82.67 & 0.000 \\
\hline
\end{tabular}

Tabel 5 menunjukkan bahwa nilai signifikansi uji hipotesis yaitu sebesar 0.000 atau lebih kecil dari 0.05 dan selisih nilai rata-rata kelas eksperimen dan kelas kontrol sebesar 4,54. Hal ini menunjukkan bahwa H0 ditolak, dan H1 diterima. Dengan demikian, dapat disimpulkan bahwa model Problem Based Learning berpengaruh terhadap kemampuan berpikir kritis siswa.

Model PBL berpengaruh terhadap kemampuan berpikir kritis siswa ketika siswa mampu memecahkan permasalahan yang dihadapi. Berdasarkan penelitian yang telah dilakukan, dapat diketahui bahwa terdapat pengaruh model PBL terhadap kemampuan berpikir kritis siswa kelas X MIA SMAN 3 Batu. Hal tersebut dapat diketahui melalui rata-rata siswa kelas eksperimen yang mendapatkan perlakuan menggunakan PBL lebih tinggi dibanding dengan siswa kelas kontrol yang menggunakan model Cooperative Learning.

Hasil analisis menunjukkan pengaruh penggunaan PBL memberikan peningkatan kemampuan berpikir kritis yang signifikan apabila dibandingkan dengan pembelajaran yang menggunakan model Cooperative Learning. Penggunaan PBL juga memberikan hasil belajar yang lebih baik daripada model pembelajaraan Cooperative Learning, terutama pada materi atmosfer. Hal ini dapat diketahui dari nilai post-test kelas eksperimen yang rata-rata hasilnya lebih tinggi apabila dibandingkan dengan nilai post-test kelas kontrol.

Penelitian yang telah dilakukan menunjukkan hasil bahwa baik kelas eksperimen maupun kelas kontrol mengalami peningkatan kemampuan berpikir kritis. Peningkatan 
didominasi oleh kelas eksperimen yang menggunakan model PBL. Hal ini menunjukkan bahwa kemampuan berpikir kritis siswa kelas eksperimen lebih tinggi apabila dibandingkan dengan kelas kontrol. Penelitian yang telah dilakukan menunjukkan hasil bahwa PBL berpengaruh terhadap kemampuan berpikir kritis siswa kelas X MIA SMAN 3 Batu.

Keberhasilan model PBL tidak terlepas dari segala keunggulan yang dimiliki model ini. Keunggulan PBL yaitu (1) meningkatkan pemahaman akan makna; (2) meningkatkan kemandirian; (3) meningkatkan pengembangan skill berpikir tingkat tinggi; (4) meningkatkan motivasi; (5) memfasilitasi relasi antar siswa; (6) meningkatkan skill dalam membangun teamwork" (Sofyan, 2015). Penggunaan PBL memberikan pengalaman yang berbeda apabila dibandingkan dengan model pembelajaran yang lain. Hal ini dikarenakan PBL memberikan kesempatan kepada siswa untuk merasakan pengalaman secara langsung dalam proses pemecahan masalah yang dilakukan siswa di lapangan.

Pembelajaran yang menggunakan PBL berfokus pada siswa dan bukan pada guru seperti pada model pembelajaran konvensional. Siswa memiliki peran yang besar terhadap pemecahan masalah yang diberikan dan pemahaman terhadap materi yang sedang dibahas. Yelland dkk menyatakan bahwa "Problem Based Learning is a student-centered method of teaching that involves learning through solving unclear but genuine problems. It is a constructivist, student-focused approach that promotes reflection, skills in communication and collaboration, and it requires reflection from multiple perspectives" (dalam Sari et. al, 2015). Terdapat tiga ciri utama dari PBL (1) merupakan rangkaian aktivitas pembelajaran yang didalamnya terdapat serangkaian kegiatan untuk siswa; (2) aktivitas pembelajaran ditujukan untuk menyelesaikan masalah; dan (3) pemecahan masalah dilakukan dengan menggunakan pendekatan berpikir secara ilmiah (Sanjaya, 2007).

Model PBL dapat memberikan pengaruh terhadap kemampuan berpikir kritis siswa secara maksimal apabila model ini diaplikasikan sesuai dengan sintaks yang berlaku. Model pembelajaran PBL memiliki sintaks sebagai berikut (1) memberi orientasi permasalahan kepada siswa; (2) mengorganisasi siswa untuk belajar; (3) membantu siswa melakukan pemecahan masalah; (4) mengembangkan penyajian hasil; (5) menganalisis dan melakukan evaluasi proses pemecahan masalah.

Selain sintaks PBL yang diimplementasikan dengan baik, faktor yang mempengaruhi kemampuan berpikir kritis siswa yang lain adalah pemilihan materi yang akan disampaikan. Tidak dapat dipungkiri bahwa pemilihan materi yang tepat dapat mempengaruhi variabel terikat yang akan diukur. Materi yang dipilih untuk penelitian ini adalah materi Atmosfer untuk kelas X.

Pelaksanaan kegiatan pembelajaran yang menggunakan PBL dilakukan pada materi unsur-unsur cuaca yakni suhu dan kelembaban udara. Materi ini dipilih menyesuaikan dengan batasan waktu penelitian yang diberikan oleh pihak sekolah. Selain itu juga menyesuaikan dengan karakteristik PBL yang menggunakan masalah sebagai basis utamanya.

Berdasarkan uraian diatas, maka dapat disimpulkan bahwa model pembelajaran dan materi yang tepat mampu melatih siswa dalam meningkatkan kemampuan berpikir kritis siswa. Pemilihan model pembelajaran jugs tetap harus disesuaikan dengan materi yang akan disampaikan, agar hasil yang didapat maksimal. 


\section{Simpulan}

Berdasarkan tujuan dan hasil penelitian yang telah diperoleh, maka penelitian ini dapat disimpulkan sebagai berikut: (1) PBL berpengaruh terhadap kemampuan berpikir kritis siswa kelas X MIA SMAN 3 Batu pada materi atmosfer. Hal ini juga menunjukkan bahwa kelas yang menggunakan PBL yaitu kelas X MIA 2 mendapatkan rata-rata nilai yang lebih tinggi apabila dibandingkan dengan kelas X MIA 1 yang tidak menggunakan PBL. (2) Indikator kemampuan berpikir kritis yang mengalami peningkatan tertinggi adalah kemampuan siswa dalam mengatur strategi dan taktik guna memecahkan permasalahan. (3) Indikator kemampuan berpikir kritis yang mengalami peningkatan terendah adalah kemampuan siswa dalam membangun keterampilan dasar dan memberikan penjelasan lanjut. (4) Model PBL sangat sesuai untuk diterapkan pada materi atmosfer, karena materi atmosfer memiliki berbagai permasalahan riil yang dapat dimanfaatkan pada kegiatan belajar mengajar untuk membentuk kemampuan berpikir kritis siswa, seperti masalah peningkatan suhu yang dapat dirasakan secara langsung oleh siswa.

\section{Daftar Rujukan}

Amin, S. (2017). Pengaruh model pembelajaran problem based learning terhadap kemampuan berpikir kritis dan hasil belajar geografi. JPG (Jurnal Pendidikan Geografi), 4(3), 25-36.

Duch, B. (1996). Problems: A key factor in PBL. About teaching, 50, 7-8.

Ennis, R. H. (2011). The nature of critical thinking: An outline of critical thinking dispositions and abilities. University of Illinois, 2(4).

Watson, G. (1980). Watson-Glaser critical thinking appraisal. San Antonio, TX: Psychological Corporation.

Kamus Besar Bahasa Indonesia. (2010). Kamus Besar Bahasa Indonesia. Jakarta: Kementerian Pendidikan dan Kebudayaan.

Kuswana, W. S. (2011). Taksonomi Berpikir. Bandung: PT Remaja Rosdakarya.

Rusman, R. (2012). Model-Model Pembelajaran Mengembangkan Profesional Guru. Jakarta: Raja Grafindo Persada.

Sanjaya, W. (2007). Buku Materi Pokok: Kajian Kurikulum dan Pembelajaran. Bandung: Sekolah Pasca Sarjana Universitas Pendidikan Indonesia.

Sari, D. T., \& Wardani, D. K. (2015, November). Penerapan Model PBL untuk Meningkatkan Kemampuan Berpikir Kritis dan Hasil Belajar Siswa pada Materi Ekonomi di SMA Negeri 3 Surakarta Tahun Pelajaran 2014/2015. In Seminar Nasional Pendidikan Ekonomi dan Bisnis 2015. Sebelas Maret University.

Sofyan, H., \& Komariah, K. (2016). Pembelajaran problem based learning dalam implementasi kurikulum 2013 Di SMK. Jurnal Pendidikan Vokasi, 6(3), 260-271. 